\title{
TENSILE PROPERTIES OF CAST NICKEL-CHROMIUM- IRON ALLOYS AND OF SOME ALLOY STEELS AT ELE- VATED TEMPERATURES
}

\author{
By William Kahlbaum ${ }^{1}$ and Louis Jordan
}

\section{ABSTRACT}

The tensile properties as measured in "short-time" tests were determined for a medium-manganese steel at $900^{\circ} \mathrm{F}$.; for a series of cast nickel-chromium-iron alloys containing about 0.5 per cent carbon, 35 per cent chromium and from 10 to 45 per cent nickel, at a temperature of $1,550^{\circ} \mathrm{F}$; and for three tungstenchromium-vanadium steels and four molybdenum-chromium-vanadium steels at temperatures of $850^{\circ}$ and $1,000^{\circ} \mathrm{F}$.

\section{CONTENTS}

I. Introduction

II. Materials

III. Method of testing 328

IV. Results and discussion 328

1. Medium-manganese steel

2. Nickel-chromium-iron alloys _._.

3. Tungsten-chromium-vanadium steels

4. Molybdenum-chromium-vanadium steels... 331

V. Summary..-_- 332

\section{INTRODUCTION}

The most recently published report by the Bureau of Standards on the so-called short-time tensile properties (that is, the strength under relatively rapid loading) of steels at elevated temperatures ${ }^{2}$ gave data on several groups of low-alloy steels. Among these were tungsten-chromium-vanadium steels with and without the addition of silicon or aluminum. Tests were also reported on wrought chromium-nickel-iron alloys containing approximately 10 per cent chromium and from 25 to 60 per cent nickel. The present report deals with the tensile properties, as determined by short-time tests, of some additional similar steels and alloys.

\section{MATERIALS}

The materials tested consisted of (1) a steel in some respects similar to the 0.45 per cent carbon "boiler drum" steel included in the preceding paper, ${ }^{3}$ but containing in the present case 1.08 per cent manganese; (2) a series of five cast nickel-chromium-iron alloys, all containing about 35 per cent chromium and from 10 to 45 per cent of nickel; (3) a series of three tungsten-chromium-vanadium steels and (4) a series of four molybdenum-chromium-vanadium steels. The chemical compositions of these materials are given in Table 1.

1 Research associate, The Midvale Co., Philadelphia, $\mathrm{Pa}$.

2 William Kahlbaum, R. L. Dowdell, and W. A. Tucker, The Tensile Properties of Alloy Steels at Elevated Temperatures as Determined by the "Short-time" Method, B. S. Jour. Research, vol. 6 (RP 270), p. 199,1930 .

See footnote, 2. 
TABLE 1.-Chemical composition

\begin{tabular}{|c|c|c|c|c|c|c|c|c|c|c|c|}
\hline Type of alloy & Designation & $\mathrm{C}$ & $\mathrm{Mn}$ & $P$ & $\mathrm{~S}$ & Si & $\mathrm{Cr}$ & $\mathrm{Ni}$ & $\mathrm{V}$ & W & Mo \\
\hline $\begin{array}{l}\text { Carbon steel (medium } \\
\text { manganese). }\end{array}$ & $8 / 1819$ & $\begin{array}{l}\text { Per } \\
\text { cent } \\
0.40\end{array}$ & $\begin{array}{l}\text { Per } \\
\text { cent } \\
1.08\end{array}$ & $\left|\begin{array}{c}P e r \\
\text { cent } \\
0.037\end{array}\right|$ & $\begin{array}{c}\text { Per } \\
\text { cent } \\
0.034\end{array}$ & $\begin{array}{l}\text { Per } \\
\text { cent } \\
0.23\end{array}$ & $\begin{array}{l}\text { Per } \\
\text { cent }\end{array}$ & $\begin{array}{l}\text { Per } \\
\text { cent }\end{array}$ & $\begin{array}{l}\text { Per } \\
\text { cent }\end{array}$ & $\begin{array}{l}\text { Per } \\
\text { cent }\end{array}$ & $\begin{array}{l}\text { Per } \\
\text { cent }\end{array}$ \\
\hline $\begin{array}{l}\text { ickel - chromium - iron } \\
\text { (cast). }\end{array}$ & $\left\{\begin{array}{l}\text { EE1522 } \\
\text { E E1523 } \\
\text { EE1524 } \\
\text { EE1525 } \\
\text { EE1520 }\end{array}\right.$ & $\begin{array}{l}.57 \\
.59 \\
.54 \\
.47 \\
.36\end{array}$ & $\begin{array}{l}.59 \\
.65 \\
.63 \\
.71 \\
.53\end{array}$ & & & $\begin{array}{l}1.04 \\
1.07 \\
\text { 1. } 13 \\
1.08 \\
1.15\end{array}$ & $\begin{array}{l}36.2 \\
35.2 \\
36.9 \\
34.5 \\
33.5\end{array}$ & \begin{tabular}{|l|}
10.2 \\
21.0 \\
30.1 \\
38.4 \\
45.2
\end{tabular} & & & $\therefore$ \\
\hline $\begin{array}{l}\text { Tungsten - chromium-va- } \\
\text { nadium steels. }\end{array}$ & $\left\{\begin{array}{l}\mathrm{H} F-1 / 16 \\
\mathrm{y} F-1 / 16 \\
\mathrm{HF}-1 / 16\end{array}\right.$ & $\begin{array}{l}.29 \\
.26 \\
.32\end{array}$ & $\begin{array}{r}.51 \\
.86 \\
1.02\end{array}$ & & & $\begin{array}{l}.58 \\
.63 \\
.17\end{array}$ & $\begin{array}{l}2.28 \\
2.25 \\
1.63\end{array}$ & & $\begin{array}{r}0.36 \\
.33 \\
.26\end{array}$ & $\begin{array}{l}1.70 \\
2.26 \\
2.17\end{array}$ & -- \\
\hline $\begin{array}{l}\text { olybdenum - chromium- } \\
\text { vanadium stcels. }\end{array}$ & $\left\{\begin{array}{l}\mathrm{HF}-1 / 166 \\
\mathrm{H} \mathrm{F}-1 / 165 \\
\mathrm{H}-1 / 177 \\
\mathrm{HF}-1 / 178\end{array}\right.$ & $\begin{array}{l}.20 \\
.22 \\
.31 \\
.21\end{array}$ & $\begin{array}{r}.45 \\
.88 \\
1.38 \\
2.23\end{array}$ & & & $\begin{array}{r}.55 \\
.18 \\
.49 \\
1.33\end{array}$ & $\begin{array}{l}\text { 1. } 55 \\
\text { 1. } 47 \\
\text { 2. } 34 \\
1.28\end{array}$ & $\cdots$ & $\begin{array}{l}.26 \\
.22 \\
.29 \\
.17\end{array}$ & $-\cdots$ & $\begin{array}{r}0.57 \\
.52 \\
.55 \\
1.00\end{array}$ \\
\hline
\end{tabular}

\section{METHOD OF TESTING}

The equipment and the method used for the short-time tension tests have been described and illustrated previously., 5 All of the tests were made with a hydraulic testing machine, and measurements of strain were made with a Tuckerman optical strain gage. ${ }^{6}$

As in one previous work, a thermocouple mounted in the fillet of the 0.505 -inch diameter test bar was used for measuring the temperature of the specimen. The temperature gradient from the center to either end of the gage length of the test bar was approximately $13^{\circ} \mathrm{F} .\left(7^{\circ} \mathrm{C}\right.$. $)$.

Proportional limits were determined by plotting the differences between observed and calculated strain and taking astrain of $1 \times 10^{-5}$ as indicating departure from a straight line. ${ }^{7}$

\section{RESULTS AND DISCUSSION}

\section{MEDIUM-MANGANESE STEEL}

The data from tests of the 0.4 per cent carbon medium manganese (1.08 per cent) steel at room temperature and at $900^{\circ} F$. are given in Table 2. The point of chief interest in these results lies in the comparison they afford with similar tests made in previous work ${ }^{8}$ on a 0.4 per cent carbon steel (boiler-drum steel) containing only a normal proportion of manganese, namely, 0.55 per cent. These previous tests of the lower manganese steel showed that it maintained a proportional limit of approximately $15,000 \mathrm{lbs}$./in. ${ }^{2}$ from $600^{\circ}$ to $750^{\circ} \mathrm{F}$., but that its proportional limit decreased noticeably, to 11,000 or $12,000 \mathrm{lbs}$./ in. ${ }^{2}$, at a temperature of $800^{\circ} \mathrm{F}$. The higher manganese steel had a proportional limit of 15,000 to $16,000 \mathrm{lbs}$. $/$ in. ${ }^{2}$ at $900^{\circ} \mathrm{F}$., fully $150^{\circ} \mathrm{F}$. higher than the temperature at which the lower-manganese steel had an equivalent proportional limit. The higher manganese steel did not, however; show a corresponding superiority in tensile strength over the lower manganese steel at the elevated temperature.

\footnotetext{
4 H. J. French, Methods of Test in Relation to Flow in Steels at Various Temperatures, Proc. Am. Soc

Test. Materials, vol. 26, Pt. II, p. 7, 1926; also Eng. News Record, vol. 97, p. 22.

Tech. Papers, No. 362, 1928 .

6 . P Tus, No. 1928.

II, p. 602, 1923. 7 L. B. Tuck

II, p. $538,1929$.

8 See footnote 2, p. 327 .
} 
TABLE 2.-Tensile properties of a medium manganese steel at elevated temperalures as delermined by short-time tests

\begin{tabular}{|c|c|c|c|c|c|c|c|}
\hline Designation 1 & $\begin{array}{l}\text { Tem- } \\
\text { pera- } \\
\text { ture of } \\
\text { test }\end{array}$ & $\begin{array}{l}\text { Propor- } \\
\text { tional } \\
\text { limit }\end{array}$ & $\begin{array}{c}\text { Teusile } \\
\text { strength }\end{array}$ & $\begin{array}{l}\text { Modulus } \\
\text { of elastic- } \\
\text { ity }\end{array}$ & $\begin{array}{c}\text { Elonga- } \\
\text { tion in } 2 \\
\text { inches }\end{array}$ & $\begin{array}{l}\text { Reduc- } \\
\text { tion of } \\
\text { area }\end{array}$ & Heat treatment prior to testing \\
\hline $8 / 1819$ & $\left\{\begin{array}{r}{ }^{\circ} F . \\
70 \\
800 \\
900\end{array}\right.$ & $\begin{array}{r}\text { Lbs./in.2 } \\
232,000 \\
16,000 \\
15,000\end{array}$ & $\begin{array}{r}\text { Lbs./in. }{ }^{2} \\
86,000 \\
59,500 \\
61,000\end{array}$ & $\begin{array}{l}\text { Lbs./in. }{ }^{2} \\
\times 10^{6} \\
21.7 \\
20.7\end{array}$ & \begin{tabular}{|} 
Per cent \\
27.5 \\
25.5 \\
25.0
\end{tabular} & $\left.\mid \begin{array}{r}\text { Per cent } \\
53.9 \\
61.3 \\
60.6\end{array}\right\}$ & $\left\{\begin{array}{l}1,600^{\circ} \mathrm{F} ., 12 \text { hours, air cooled; } \\
1,200^{\circ} \mathrm{F} ., 10 \text { hours, cooled } \\
\text { slowly. }\end{array}\right.$ \\
\hline
\end{tabular}

1 See Table 1 for chemical composition.

2 Determined by the Midvale Co. A strain of $5 \times 10^{-5}$ taken as indicating departure from a straight line.

\section{NICKEL-CHROMIUM-IRON ALLOYS}

The results of short-time tensile tests at $1,550^{\circ} \mathrm{F}$. of cast nickelchromium-iron alloys are given in Table 3 . These alloys contained from 0.4 to 0.6 per cent carbon and about 1 per cent silicon and 35 per cent chromium. The nickel content of EE1522 was approximately 10 per cent and this increased to about 45 per cent in the last alloy of the series, EE1526.

This series showed no significant differences in the proportional limits of the various alloys at $1,550^{\circ} \mathrm{F}$. There was, however, a progressive increase in the ductility of the alloy as the nickel content increased from 10 to 45 per cent, and above 30 per cent nickel there was a noticeable decrease in tensile strength.

It is in this case also of interest to recall the results of short-time tensile tests given in a previous report ${ }^{9}$ for nickel-chromium-iron alloys containing 10 per cent chromium and either 35 or 57 per cent nickel. Only a very general correlation is possible as the earlier tests were made with maximum testing temperatures of only $1,360^{\circ} \mathrm{F}$. as compared with $1,550^{\circ} \mathrm{F}$. for the more recent tests; the alloys tested in the earlier work were rolled material and in the later work were "as cast"; and also the high-nickel alloy of the earlier work contained over 3 per cent tungsten.

TABLE 3.-Tensile properties of cast nickel-chromium-iron alloys at $1,550^{\circ} \mathrm{F}$. as determined by short-time tests

\begin{tabular}{l} 
Designation 1 \\
\hline EE1522_.
\end{tabular}

1 See Table 1 for chemical compositions.

- See footnote 2, p. 327. 
Nevertheless, it is to be noted that the tensile strengths of the cast alloys of the present series, containing 35 per cent chromium and either 10, 20, or 30 per cent nickel, were of the order of $50,000 \mathrm{lbs} . / \mathrm{in}^{2}{ }^{2}$ and the proportional limits of the order of 5,000 to 7,000 lbs./in. ${ }^{2}$ at $1,550^{\circ}$ F. as compared with tensile strengths of only 35,000 to $40,000 \mathrm{lbs}$./in. ${ }^{2}$ and proportional limits of 5,000 to $6,000 \mathrm{lbs}$./in. ${ }^{2}$ at $1,360^{\circ} \mathrm{F}$. for rolled alloys containing 35 per cent nickel and 10 per cent chromium.

Increased proportional limits and tensile strengths in alloys of this type at temperatures of $1,300^{\circ}$ to $1,500^{\circ} \mathrm{F}$. appear to result from an increased chromium content rather than an increased nickel content. With this increase in strength, there is also noticeably less ductility as measured by elongation and reduction of area.

\section{TUNGSTEN-CHROMIUM-VANADIUM STEEL}

The chief differences in the chemical compositions of the three tungsten-chromium-vanadium steels (Table 1) were that the first of the series $(\mathrm{HF}-1 / 169)$ had a tungsten content of only 1.70 per cent, which was somewhat below the normal composition of the series; the second of the series (HF-1/167) may be considered of the normal composition, namely, about $2 \frac{1}{4}$ per cent each of chromium and tungsten; the last steel of the group was low in chromium (1.63 per cent) but also had a manganese content (1.02 per cent) distinctly higher than the normal for the group.

All of these steels were tested after normalizing from $1,700^{\circ} \mathrm{F}$., hardening, and tempering at $1,200^{\circ} \mathrm{F}$. The hardening treatment consisted of air quenching from a temperature $50^{\circ} \mathrm{F}$. above the upper critical temperature of the individual steel. The exact temperatures are shown in Table 4.

The results of the short-time high-temperature tests of these steels (Table 4) did not show any very striking differences in the behavior of the three steels. On the whole, the steel containing 1 per cent manganese (HF-1/168), with the lower chromium and the normal tungsten content, appeared to be superior with respect to the maintenance of a high proportional limit at elevated temperatures.

TABLE 4.-Tensile properties of tungsten-chromium-vanadium steels at elevated temperatures as determined by short-time tests

\begin{tabular}{|c|c|c|c|c|c|c|c|}
\hline Designation 1 & $\begin{array}{l}\text { Tem- } \\
\text { pera- } \\
\text { ture of } \\
\text { test }\end{array}$ & $\begin{array}{l}\text { Propor- } \\
\text { tional } \\
\text { limit }\end{array}$ & $\begin{array}{l}\text { Tensile } \\
\text { strength }\end{array}$ & $\begin{array}{l}\text { Modu- } \\
\text { lus of } \\
\text { elastic- } \\
\text { ity }\end{array}$ & $\begin{array}{l}\text { Elonga- } \\
\text { tion in } \\
2 \text { inches }\end{array}$ & $\begin{array}{l}\text { Reduc- } \\
\text { tion of } \\
\text { area }\end{array}$ & Eardening heat treatment 2 \\
\hline $\mathrm{HF}-1 / 169$ & $\left\{\begin{array}{r}{ }^{\circ} F . \\
70 \\
850 \\
1,000\end{array}\right.$ & $\begin{array}{r}\text { Lbs./in.2 }{ }^{2} \\
392,000 \\
32,000 \\
26,000\end{array}$ & $\begin{array}{r}\text { Lb.s./in. }{ }^{2} \\
128,000 \\
86,000 \\
71,500\end{array}$ & $\begin{array}{c}\text { Lbs./in. }{ }^{2} \\
\times 10^{\circ} \\
25.2 \\
22.1\end{array}$ & \begin{tabular}{|} 
Per cent \\
20.2 \\
22.0 \\
23.5
\end{tabular} & \begin{tabular}{|} 
Per cent \\
62.6 \\
64.7 \\
72.9
\end{tabular} & $1,515^{\circ} \mathrm{F} ., 30$ minutes, air cooled. \\
\hline 且 $F-1 / 167 \ldots$ & $\left\{\begin{array}{r}70 \\
850 \\
1,000\end{array}\right.$ & $\begin{array}{r}107,000 \\
30,000 \\
16,000\end{array}$ & $\begin{array}{r}139,500 \\
98,500 \\
77,500\end{array}$ & $\begin{array}{l}23.6 \\
22.1\end{array}$ & $\begin{array}{l}19.2 \\
21.5 \\
23.0\end{array}$ & $\begin{array}{l}59.9 \\
62.3 \\
70.1\end{array}$ & $1,510^{\circ} \mathrm{F} ., 30$ minutes, air cooled \\
\hline HF-1/168.. & $\left\{\begin{array}{r}70 \\
850 \\
1,000\end{array}\right.$ & $\begin{array}{r}3109,000 \\
43,000 \\
24,000\end{array}$ & $\begin{array}{r}136,500 \\
99,500 \\
84,500\end{array}$ & $\begin{array}{l}24.3 \\
19.9\end{array}$ & $\begin{array}{l}18.2 \\
19.0 \\
22.5\end{array}$ & $\begin{array}{l}55.7 \\
54.9 \\
65.6\end{array}$ & $1,480^{\circ} \mathrm{F} ., 30$ minutes, air cooled \\
\hline
\end{tabular}

1 See Table 1 for chemical compositions.

2 All specimens were normalized before the hardening treatment and tempered after the hardening treatment indicated in the last column of this table. In all cases the normalizing treatment' consisted of heating at $1,700^{\circ} \mathrm{F}$. for 30 minutes and cooling in air; the tempering treatment, of heating at $1,200^{\circ} \mathrm{F}$. for 30 minutes and cooling in air.

3 Determined by The Midvale Co. A strain of:5 ${ }_{*}^{7} 510^{-5}$ taken as indicating departure from_a straight line. 


\section{MOLYBDENUM-CHROMIUM-VANADIUM STEELS}

The molybdenum-chromium-vanadium steels are listed in both Table 1 and Table 5 in the order of increasing manganese content. The second steel of the series differed from the first in that it had slightly higher carbon ( 0.29 per cent) and manganese ( 0.88 per cent) contents than the first steel of the series $(0.20$ per cent carbon, 0.45 per cent manganese). This difference in composition apparently accounted for a distinctly higher proportional limit and tensile strength in the steel of higher carbon and manganese contents at temperatures of $850^{\circ}$ and $1,000^{\circ} \mathrm{F}$. Further increase in the proportion of manganese, and also of chromium, in the third steel of the series (HF$1 / 177$ ) resulted in a still higher proportional limit at $850^{\circ} \mathrm{F}$., but produced no increase in either proportional limit or tensile strength at $1,000^{\circ} \mathrm{F}$. The fourth and last steel of this series had the highest manganese content of all (2.23 per cent), about double the molybdenum content (1.00 per cent) of the other steels, and a high silicon content (1.33 per cent). This steel had tensile strengths, at the high temperatures, equivalent to or higher than the other steels of the series. Its proportional limit at $850^{\circ} \mathrm{F}$. was also high. Its proportional limit at $1,000^{\circ} \mathrm{F}$., however, failed to show an equivalent increase and was only of the order of the proportional limit of the first steel of this series, the low-carbon, low-manganese composition, at the corresponding temperature. In previous work ${ }^{10}$ it has been observed that 1.25 per cent silicon had a very marked effect in lowering the proportional limit of a tungsten-chromium-vanadium steel at about $1,000^{\circ} \mathrm{F}$.

TABLE 5.-Tensile properties of molybdenum-chromium-vanadium steels at elevated temperatures as determined by short-time tests

\begin{tabular}{|c|c|c|c|c|c|c|c|}
\hline Designation 1 & $\begin{array}{l}\text { Tem- } \\
\text { pera- } \\
\text { ture of } \\
\text { test }\end{array}$ & $\begin{array}{l}\text { Propor- } \\
\text { tional } \\
\text { limit }\end{array}$ & $\begin{array}{l}\text { Tensile } \\
\text { strength }\end{array}$ & $\begin{array}{l}\text { Modulus } \\
\text { of elas- } \\
\text { ticity }\end{array}$ & $\begin{array}{l}\text { Elonga- } \\
\text { tion in } \\
2 \text { inches }\end{array}$ & $\begin{array}{l}\text { Reduc- } \\
\text { tion of } \\
\text { area }\end{array}$ & Hardening heat treatment 2 \\
\hline HF $-1 / 166 \ldots$ & $\left\{\begin{array}{r}{ }^{\circ} F . \\
70 \\
850 \\
1,000\end{array}\right.$ & $\begin{array}{r}\text { Lbs./in. }{ }^{2} 60,000 \\
25,000 \\
19,000\end{array}$ & $\begin{array}{r}\text { Lbs./in. } \\
104,000 \\
83,000 \\
71,000\end{array}$ & $\begin{array}{r}\text { Lbs./in. }{ }^{2}{ }^{2} .10^{2} \\
24.6\end{array}$ & $\begin{array}{c}\text { Per cent } \\
24.7 \\
23.5 \\
24.0\end{array}$ & $\begin{array}{r}\text { Per cent } \\
66.2 \\
67.5 \\
71.6\end{array}$ & $\left\{1,490^{\circ} \mathrm{F} ., 30\right.$ minutes, air cooled. \\
\hline HF $-1 / 165$ & $\left\{\begin{array}{r}70 \\
850 \\
1,000\end{array}\right.$ & $\begin{array}{r}380,000 \\
32,000 \\
26,000\end{array}$ & $\begin{array}{r}118,000 \\
96,000 \\
81,000\end{array}$ & $\begin{array}{r}24.0 \\
21.7\end{array}$ & $\begin{array}{l}20.7 \\
21.5 \\
23.5\end{array}$ & $\begin{array}{l}65.0 \\
67.5 \\
74.5\end{array}$ & $1,460^{\circ} \mathrm{F} ., 30$ minutes, air cooled. \\
\hline HF-1/177 & $\left\{\begin{array}{r}70 \\
850 \\
1,000\end{array}\right.$ & $\begin{array}{r}375,000 \\
37,000 \\
25,000\end{array}$ & $\begin{array}{r}112,000 \\
97,000 \\
71,500\end{array}$ & $\begin{array}{l}24.8 \\
20.2\end{array}$ & $\begin{array}{l}23.0 \\
20.5 \\
25.0\end{array}$ & $\begin{array}{l}63.3 \\
60.1 \\
73.3\end{array}$ & $1,460^{\circ} \mathrm{F} ., 30$ minutes, air cooled. \\
\hline HF-1/178 ... & $\left\{\begin{array}{r}70 \\
850 \\
1,000\end{array}\right.$ & $\begin{array}{r}374,000 \\
36,000 \\
20,000\end{array}$ & $\begin{array}{r}124,000 \\
104,000 \\
78,500\end{array}$ & $\begin{array}{l}23.3 \\
18.9\end{array}$ & $\begin{array}{l}21.5 \\
23.5 \\
27.0\end{array}$ & $\begin{array}{l}54.4 \\
63.5 \\
77.4\end{array}$ & $1,460^{\circ} \mathrm{F},, 30$ minutes, air cooled. \\
\hline
\end{tabular}

1 See Table 1 for chemical compositions.

2 All specimens were normalized before the hardening treatment and tempered after the hardening treatment indicated in the last column of this table. In all cases the normalizing treatment consisted of heating at $1,700^{\circ} \mathrm{F}$. for 30 minutes and cooling in air; the tempering treatment, of heating at $1,200^{\circ} \mathrm{F}$. for 30 minutes and cooling in air.

${ }^{3}$ Determined by The Midvale Co. A strain of $5 \times 10^{-5}$ taken as indicating departure from a straight lino,

${ }^{10}$ See footnote 2, p. 327 . 


\section{SUMMARY}

1. Short-time tensile tests at elevated temperatures were made of a medium-manganese steel; of a series of cast nickel-chromium-iron alloys containing about 0.50 per cent carbon, 35 per cent chromium, and nickel from 10 to 45 per cent; and of two series of low-alloy steels, namely, tungsten-chromium-vanadium and molybdenum-chromiumvanadium steels, all normalized, hardened, and tempered at $1,200^{\circ} \mathrm{F}$.

2 . The medium-manganese steel (1.08 per cent) had a proportional limit of 15,000 to $16,000 \mathrm{lbs}$. $/ \mathrm{in}^{2}$ at $900^{\circ} \mathrm{F}$. This is fully $150^{\circ} \mathrm{F}$. higher than the temperature at which a 0.55 per cent manganese boiler-drum steel of the same carbon content ( 0.4 per cent carbon) possessed the same proportional limit.

3. The nickel-chromium alloys showed no marked change in proportional limit at $1,550^{\circ} \mathrm{F}$. over the range of composition studied. With nickel contents over 30 per cent tensile strengths of the alloys decreased noticeably and the ductility increased.

4. A medium-manganese content (1.02 per cent) in one of the steels of the tungsten-chromium-vanadium series was accompanied by proportional limits as high as or higher than in the other steels of the series.

5. Increased manganese contents (up to 1.4 per cent) in the molybdenum-chromium-vanadium steels resulted in higher proportional limits at $850^{\circ}$ and $1,000^{\circ} \mathrm{F}$. A steel having a still higher manganese content (2.23 per cent) accompanied by high silicon (1.33 per cent) and 1.00 per cent molybdenum had a high proportional limit at $850^{\circ} \mathrm{F}$., but a comparatively low proportional limit at a temperature of $1,000^{\circ} \mathrm{F}$. Similarly, low proportional limits at $1,000^{\circ} \mathrm{F}$. were observed in previous work with tungsten-chromiumvanadium steels having a high silicon content (1.25 per cent $\mathrm{Si}$ ).

Washington, July 6, 1932. 